\title{
A LITERATURE REVIEW OF THE FACTORS LIMITING THE APPLICATION OF BIM IN THE CONSTRUCTION INDUSTRY
}

\author{
Chengshuang SUN ${ }^{\mathrm{a}}$, Shaohua JIANG ${ }^{\mathrm{b}}$, Miroslaw J. SKIBNIEWSKIc, \\ Qingpeng MAN ${ }^{\mathrm{a}}$, Liyin SHEN ${ }^{\mathrm{d}}$ \\ ${ }^{a}$ School of Management, Harbin Institute of Technology, China \\ ${ }^{b}$ Department of Construction Management, Dalian University of Technology, China \\ ${ }^{c}$ Department of Civil and Environmental Engineering, University of Maryland, \\ College Park, MD 20742-8411, USA \\ ${ }^{d}$ School of Construction Management and Real Estate, Chongqing University, China
}

Received 09 July 2013; accepted 14 March 2015

\begin{abstract}
Building Information Modeling (BIM) has had a profound effect on the construction industry. It has greatly improved coordination among stakeholders, enhanced productivity, and increased profits. However, many factors still limit the application of BIM in the construction industry. This study conducts a literature review to identify these negative factors. Firstly, twenty-two sub-factors are identified and classified into five categories: Technology, Cost, Management, Personnel, and Legal. Secondly, some suggestions for eliminating these limiting factors are given. Finally, the study also identifies further research directions for improving BIM theory and applying BIM technology widely and successfully. The results of this study will provide support for practitioners who are using or plan to use BIM.
\end{abstract}

Keywords: building information modeling, BIM, construction industry.

JEL Classification: L74, L86, O14, O33.

\section{Introduction}

Building Information Modeling (BIM) technology is changing the construction industry. It is the future of the AEC industry (Hoffer 2008). Market research from National Institute of Building Sciences (NIBS 2007) shows that future building design and construction will increasingly rely on BIM. Currently, BIM is being applied in many stages of the construction project lifecycle, creating significant benefits for the stakeholders and society. For instance, the design team at the General Motors Production Plant in Flint, Michigan, estimates that the use of BIM technology, specifically automated clash detection, saved $3-5 \%$ in overall

Corresponding author Chengshuang Sun

E-mail: chshsun@hit.edu.cn 
costs, and the 3D digital workflow contributed an additional $2-4 \%$ in cost and time savings (Eastman et al. 2008). Another project, the Hilton Aquarium in Atlanta, Georgia, used BIM for design coordination, clash detection, and work sequencing. The cost of the BIM was $\$ 90,000,0.2 \%$ of the project budget ( $\$ 40,000$ paid by owner), and the cost benefit was $\$ 600,000$. Most of the savings were from the elimination of clashes, resulting in 1,143 saved hours (Azhar et al. 2011). Furthermore, a web survey conducted by Autodesk (2008) suggests that BIM increases productivity after an average of three to four months, is more accessible than general CAD applications, enhances workflow after training, benefits owners, designers, and contractors, reduces the risk of design error, and enables communication and coordination among the project team. Although BIM has many benefits, there are also limitations and barriers that have slowed BIM application (Yan, Damian 2008; Zhang, Gao 2013), and BIM application is still in an infant stage to some extent (Cao et al. 2015).

This study uses a literature review to identify the factors limiting the application of BIM in the construction industry, sets up a detailed classification of these limiting factors, and presents some suggestions for their management or avoidance. The research results will encourage the wider application of BIM in the construction industry.

\section{BIM}

\subsection{Definition of BIM}

BIM, as a popular term, is not new. The concept, approaches, and methodologies that we now identify same as BIM have been studied for many years. One of the early documented example is a working prototype, the Building Description System presented by the "father of BIM," Chuck Eastman (Eastman et al. 2008) in 1975. Since then, although most researchers and organizations have focused on CAD-related studies due to the successful application of CAD in the construction industry, there have been many studies of BIMrelated technologies, especially in the last decade. As a result of the variety in understandings of intelligent building and research emphases, many new terms relating to BIM have been developed. Bilal Succar (2009) identifies some of the more widely used terms in both the research and industry literature: Asset Lifecycle Information System, Building Product Models, BuildingSMART ${ }^{\mathrm{TM}}$, Integrated Design Systems, Integrated Project Delivery, nD Modeling, Virtual Building ${ }^{\mathrm{TM}}$, Virtual Design and Construction, and 4D Product Models. Even the term BIM, popularized in 2002 by Jerry Laiserin (2002), has no widely accepted definition. Table 1 sets out some of the more important definitions.

Table 1 demonstrates that most definitions of BIM use it as a term to describe a modeling process or activity rather than a model. In addition, the characteristics of BIM can be seen in the following definitions.

- It is a group of datasets that together contain all of the information about a building; these data can be shared and used in the lifecycle of a project by all of the stakeholders.

- It is a modeling technology and an integrated process used to create a building information model; this model is an intelligent and parametric digital representation of the building. 
Table 1. BIM definitions

\begin{tabular}{ll}
\hline $\begin{array}{l}\text { Organization } \\
\text { or Researcher }\end{array}$ & \multicolumn{1}{c}{ Definition } \\
\hline $\begin{array}{l}\text { NIBS } \\
(2007)\end{array}$ & $\begin{array}{l}\text { A digital representation of the physical and functional characteristics of a facility, } \\
\text { which serves as a shared knowledge resource for information about a facility that } \\
\text { forms a reliable basis for decisions during its lifecycle from inception onward. }\end{array}$ \\
\hline $\begin{array}{l}\text { GSA } \\
(2007)\end{array}$ & $\begin{array}{l}\text { BIM is the development and use of a multi-faceted computer-software data model } \\
\text { that not only documents a building design, but simulates the construction and } \\
\text { operation of a new capital facility or a recapitalized (modernized) facility. The } \\
\text { resulting model is a data-rich, object-based, intelligent, and parametric digital } \\
\text { representation of the facility from which views appropriate to various users needs } \\
\text { can be extracted and analyzed to generate feedback on and improvement of the } \\
\text { facility design. }\end{array}$ \\
\hline
\end{tabular}

Eastman et al. A modeling technology and associated set of processes for producing, (2008) communicating, and analyzing building models.

Harness

(2008)

A building information model (the model) is a digital representation of the physical and functional characteristics of the project. BIM is the process and technology used to create the model.

Autodesk $\quad$ BIM is an integrated process that vastly improves project understanding and allows (2012) for predictable outcomes. This visibility enables all of the project team members to stay coordinated, improve accuracy, reduce waste, and make informed decisions earlier in the process - helping to ensure the project's success.

Tekla The process of modeling and communicating the structure of a building in detail (2013) to benefit the entire building lifecycle.

- It can greatly benefit the entire building lifecycle, such as improving communication, coordination, collaboration, and cooperation, reducing building waste, and forming a reliable basis for decisions.

In this paper, for avoiding the confusion about the abbreviation of BIM, we use the term "BIM" to refer to the processes of modeling, collaboration and integration and "building information model" to refer to the object-based model or a group of datasets.

\subsection{BIM uses in the construction industry}

BIM can be applied to every stage of a construction project from inception to demolition (Autodesk 2002; Eastman et al. 2008; Azhar et al. 2011).

- Visualization: 3D views, renderings, and walk-throughs can be easily generated.

- Change management: change to any part of a building is automatically coordinated in all of the other parts.

- Code Checking: the building information models can be used by municipal building departments for the approval of building projects.

- Clash Detection: as building information models are created early in the process, all of the major systems, such as piping, plumbing, construction equipment, and sheet metal ductwork can be visually checked for time-space conflicts in the preconstruction phase. 
- Fabrication: all of the shop drawings of the building systems for the fabricators can be more easily and quickly produced from the building information models than traditional mode.

- Communication and collaboration: all of the information on the participants, building materials, building machinery, planning, and everything else is incorporated into the building information model so that communication and collaboration between stakeholders can be supported through one consistent model.

- Time and cost management: 4D and 5D are model-based deliverables, which can be used for activities such as constructability analysis, project delivery schedules, material requirement planning, and cost estimating.

- Green building: building information models can be transferred into other software programs for further analysis of the building's comfort, lighting, energy performance, etc.

- Facilities management: BIM can be used for space management and maintenance operations in facilities management.

\subsection{Benefits of BIM}

Many scholars have studied the benefits of BIM for the AEC/FM industry. For example, Chuck Eastman et al. (2008) discuss the benefits at each of the four construction stages: pre-construction, design, construction and fabrication, and post-construction, although some of the benefits they discuss are not currently available but can be expected as BIM technology develops. Salman Azhar et al. (2011) summarize eight kinds of benefits: accurate geometrical representation, faster and more effective processes, better design, controlled whole-life costs and environmental data, better production quality, automated assembly, better customer service, and lifecycle data. Case studies of construction projects that use BIM indicate that there are $8-15 \%$ savings on new projects and up to $35 \%$ savings on repeat projects; these savings are the result of reusing information, having more (and better) decision-making information earlier, and better early-phase analysis (Jernigan 2007).

Previous studies suggest that the application of BIM has the following benefits (Gilligan, Kunz 2007; Azhar et al. 2008, 2011; Nisbet, Dinesen 2010; German 2012):

- reducing costs and improving the accuracy and speed of cost estimates;

- avoiding clashes (up to $10 \%$ of the contract value is saved by detecting clashes);

- shortening time (up to $7 \%$ reduction in project time);

- ensuring lower whole-life costs for the asset through sustainable design;

- facilitating construction coordination;

- reducing requests for information and change orders (up to $40 \%$ elimination of unbudgeted change);

- facilitating generation of construction documents;

- facilitating the simulation and visualization of the construction project. 


\section{Research methodology}

To collect and review the previous research related to the factors limiting the application of BIM, a typical literature review is adopted. The research procedure consists of three steps:

The first step is collecting as many relevant studies as possible. Two search conditions are used. Due to the nonexclusive definitions of BIM, the terms in the first search condition are "Building Information Modeling" or "BIM" or "Building Information Model" or "Virtual Design and Construction" or " $4 \mathrm{D}$ " or " $\mathrm{nD}$ ". There are many synonyms for "factors limiting the application", so the second search condition includes the terms "barrier", "inhibit", "drawback", "obstacle", "flaw", or "impediment". The search encompasses many types of resources including books, reports, journal/conference databases, and websites. The journal/conference databases are the EI Village (Compendex), ASCE library, Elsevier Science, Science Citation Index (Web of Science), etc. The reports are from well-known companies that have developed BIM tools, such as Autodesk', Graphisoft ${ }^{\circ}$, and Bentley". For collecting as many studies as possible, after an initial set of studies is identified by using keywords, the references in these studies is used as the starting point to find other studies.

The second step is analyzing the material collected by the search. The factors limiting the application of BIM are described and classified.

The last step is making suggestions to eliminate these negative factors.

\section{Factors limiting the application of BIM}

\subsection{Summary of factors identified in the literature review}

The application of BIM is beneficial to the construction industry and gives a high Return on Investment (ROI), ranging from $634 \%$ to $1633 \%$ (Azhar et al. 2011), from $16 \%$ to $1654 \%$ through three cases studies (Giel, Issa 2013). Yet, BIM application is much slower than anticipated (Fischer, Kunz 2004). There are many previous studies of the factors that are limiting the application of BIM. Table 2 shows a summary of the factors identified in the literature review.

Table 2. Summary of limitation factors

\begin{tabular}{|c|c|c|c|}
\hline No. & Factors & Reference & Sum \\
\hline 1 & $\begin{array}{l}\text { Need to educate } \\
\text { professionals about } \\
\text { BIM (P1) }\end{array}$ & $\begin{array}{l}\text { Gilligan, Kunz 2007; Eastman et al. 2008; Post 2008; Young et al. } \\
\text { 2008; Yan, Damian 2008; Hartmann, Fischer 2008; Arayici et al. } \\
\text { 2009, 2011; Sacks, Barak 2010; Singh et al. 2011; Gerber et al. } \\
\text { 2011; Nejat et al. 2012; Gledson et al. 2012; Giel, Issa 2013; Eadie } \\
\text { et al. 2013; Porwal, Hewage 2013; Zhang, Gao 2013; Migilinskas } \\
\text { et al. 2013; Volk et al. 2014 }\end{array}$ & 19 \\
\hline 2 & $\begin{array}{l}\text { Lack of data } \\
\text { interoperability (T5) }\end{array}$ & $\begin{array}{l}\text { Bernstein, Pittman 2004; Eastman et al. 2008; Post 2008; } \\
\text { McAdam 2010; Azhar et al. 2011; Kim, Anderson 2012; McAuley } \\
\text { et al. 2012; Rezgui et al. 2013; Porwal, Hewage 2013; Aram et al. } \\
\text { 2013; Migilinskas et al. 2013; Gupta et al. 2014; Dong et al. 2014; } \\
\text { Miettinen, Paavola 2014; Volk et al. 2014; Cao et al. } 2015\end{array}$ & 16 \\
\hline
\end{tabular}


Continue of Table 2

\begin{tabular}{|c|c|c|c|}
\hline No. & Factors & Reference & Sum \\
\hline 3 & $\begin{array}{l}\text { Changes in } \\
\text { workflows and } \\
\text { inappropriate } \\
\text { business models } \\
\text { (M4) }\end{array}$ & $\begin{array}{l}\text { Bernstein, Pittman 2004; Howell, Batcheler 2004; Méndez } \\
\text { 2006; Gilligan, Kunz 2007; Gu et al. 2007; Eastman et al. 2008; } \\
\text { Post 2008; Arayici et al. 2009, 2011; Singh et al. 2011; Jensen, } \\
\text { Jóhannesson 2012; Gledson et al. 2012; Rezgui et al. 2013; } \\
\text { Porwal, Hewage 2013; Cao et al. } 2015\end{array}$ & 15 \\
\hline 4 & $\begin{array}{l}\text { No well-developed } \\
\text { practical strategies } \\
\text { and standards (M2) }\end{array}$ & $\begin{array}{l}\text { Bernstein, Pittman 2004; Eastman et al. 2008; McAdam 2010; } \\
\text { Azhar et al. 2011; Singh et al. 2011; Arayici et al. 2011; Jensen, } \\
\text { Jóhannesson 2012; Gledson et al. 2012; McAuley et al. 2012; } \\
\text { Porwal, Hewage 2013; Migilinskas et al. 2013; Dong et al. 2014; } \\
\text { Miettinen, Paavola 2014 }\end{array}$ & 13 \\
\hline 5 & $\begin{array}{l}\text { Habitual resistance } \\
\text { to change }(\mathrm{P} 2)\end{array}$ & $\begin{array}{l}\text { Howell, Batcheler 2004; Méndez 2006; Gu et al. 2007; Eastman } \\
\text { et al. 2008; Yan, Damian 2008; Singh et al. 2011; Arayici et al. } \\
\text { 2011; Jensen Jóhannesson 2012; Gledson et al. 2012; Rezgui et al. } \\
\text { 2013; Eadie et al. 2013; Volk et al. } 2014\end{array}$ & 12 \\
\hline 6 & $\begin{array}{l}\text { Cost of specialized } \\
\text { software (C2) }\end{array}$ & $\begin{array}{l}\text { Gu et al. 2007; Post 2008; Young et al. 2008; Arayici et al. 2009; } \\
\text { Giel, Issa 2011, 2013; Rezgui et al. 2013; Eadie et al. 2013; } \\
\text { Porwal, Hewage 2013; Zhang, Gao 2013; Migilinskas et al. } 2013\end{array}$ & 11 \\
\hline 7 & $\begin{array}{l}\text { Functionality of } \\
\text { BIM tools (T1) }\end{array}$ & $\begin{array}{l}\text { Howell, Batcheler 2004; Méndez 2006; Eastman et al. 2008; } \\
\text { Post 2008; Hartmann, Fischer 2008; Pihlak et al. 2011; Jensen, } \\
\text { Jóhannesson 2012; McAuley et al. 2012; Aram et al. 2013; } \\
\text { Miettinen, Paavola 2014; Volk et al. 2014 }\end{array}$ & 11 \\
\hline 8 & $\begin{array}{l}\text { Cost in terms of } \\
\text { time and training } \\
(\mathrm{C} 1)\end{array}$ & $\begin{array}{l}\text { Méndez 2006; Arayici et al. 2009; Giel, Issa 2011, 2013; Gledson } \\
\text { et al. 2012; Rezgui et al. 2013; Eadie et al. 2013; Porwal, Hewage } \\
\text { 2013; Zhang, Gao 2013; Migilinskas et al. } 2013\end{array}$ & 10 \\
\hline 9 & $\begin{array}{l}\text { Cost of required } \\
\text { hardware upgrades } \\
\text { (C3) }\end{array}$ & $\begin{array}{l}\text { Post 2008; Young et al. 2008; Arayici et al. 2009; Giel, Issa 2011, } \\
\text { 2013; Rezgui et al. 2013; Eadie et al. 2013; Porwal, Hewage 2013; } \\
\text { Zhang, Gao 2013; Migilinskas et al. } 2013\end{array}$ & 10 \\
\hline 10 & $\begin{array}{l}\text { Contractual } \\
\text { environment (L4) }\end{array}$ & $\begin{array}{l}\text { Gilligan, Kunz 2007; Eastman et al. 2008; Hartmann, Fischer } \\
\text { 2008; McAdam 2010; Gledson et al. 2012; Rezgui et al. 2013; } \\
\text { Eadie et al. 2013; Migilinskas et al. 2013; Miettinen, Paavola } \\
\text { 2014; Volk et al. } 2014\end{array}$ & 10 \\
\hline 11 & $\begin{array}{l}\text { Responsibility } \\
\text { between } \\
\text { stakeholders (L1) }\end{array}$ & $\begin{array}{l}\text { Gilligan, Kunz 2007; Eastman et al. 2008; McAdam 2010; Azhar } \\
\text { et al. 2011; Singh et al. 2011; Arayici et al. 2011; Gledson et al. } \\
\text { 2012; Rezgui et al. 2013; Volk et al. } 2014\end{array}$ & 9 \\
\hline 12 & $\begin{array}{l}\text { Ownership of the } \\
\text { BIM data and its } \\
\text { copyright (L3) }\end{array}$ & $\begin{array}{l}\text { Gu et al. 2007; Eastman et al. 2008; McAdam 2010; Azhar et al. } \\
\text { 2011; Gledson et al. 2012; Rezgui et al. 2013; Eadie et al. 2013; } \\
\text { Porwal, Hewage 2013; Volk et al. } 2014\end{array}$ & 9 \\
\hline 13 & $\begin{array}{l}\text { Fragmented nature } \\
\text { of construction } \\
\text { industry (M1) }\end{array}$ & $\begin{array}{l}\text { Bernstein, Pittman 2004; Howell, Batcheler 2004; Gu et al. 2007; } \\
\text { Singh et al. 2011; Jensen, Jóhannesson 2012; McAuley et al. 2012; } \\
\text { Rezgui et al. 2013; Miettinen, Paavola 2014; Volk et al. } 2014\end{array}$ & 9 \\
\hline 14 & $\begin{array}{l}\text { Lack of managers' } \\
\text { and owners' } \\
\text { awareness and } \\
\text { support (M3) }\end{array}$ & $\begin{array}{l}\text { Gilligan, Kunz 2007; Young et al. 2008; Arayici et al. 2011; Nejat } \\
\text { et al. 2012; Eadie et al. 2013; Porwal, Hewage 2013; Migilinskas } \\
\text { et al. 2013; Cao et al. } 2015\end{array}$ & 8 \\
\hline 15 & $\begin{array}{l}\text { Accessibility of BIM } \\
\text { tools (T2) }\end{array}$ & $\begin{array}{l}\text { Méndez 2006; Gilligan, Kunz 2007; Eastman et al. 2008; Gledson } \\
\text { et al. 2012; McAuley et al. 2012; Porwal, Hewage 2013; Dong } \\
\text { et al. 2014; Volk et al. } 2014\end{array}$ & 8 \\
\hline
\end{tabular}


End of Table 2

\begin{tabular}{|c|c|c|c|}
\hline No. & Factors & Reference & Sum \\
\hline 16 & $\begin{array}{l}\text { Safety and reliability } \\
\text { of building } \\
\text { information (L5) }\end{array}$ & $\begin{array}{l}\text { Méndez 2006; Eastman et al. 2008; Post 2008; McAdam 2010; } \\
\text { Rezgui et al. 2013; Porwal, Hewage 2013; Miettinen, Paavola } \\
\text { 2014; Volk et al. } 2014\end{array}$ & 8 \\
\hline 17 & $\begin{array}{l}\text { Missing insurance } \\
\text { framework for BIM } \\
\text { application (L2) }\end{array}$ & $\begin{array}{l}\text { Eastman et al. 2008; Post 2008; Hartmann, Fischer 2008; } \\
\text { McAdam 2010; Gledson et al. 2012; Eadie et al. } 2013\end{array}$ & 6 \\
\hline 18 & $\begin{array}{l}\text { Need for } \\
\text { sophisticated data } \\
\text { management (T4) }\end{array}$ & $\begin{array}{l}\text { Howell, Batcheler 2004; Eastman et al. 2008; Azhar et al. 2011; } \\
\text { Ding et al. 2014; Volk et al. 2014; Chen et al. } 2015\end{array}$ & 6 \\
\hline 19 & $\begin{array}{l}\text { Not familiar } \\
\text { enough with BIM } \\
\text { capabilities (P3) }\end{array}$ & $\begin{array}{l}\text { Gu et al. 2007; Arayici et al. 2009, 2011; Singh et al. 2011; Jensen, } \\
\text { Jóhannesson } 2012\end{array}$ & 5 \\
\hline 20 & $\begin{array}{l}\text { Lack of protocols } \\
\text { (L6) }\end{array}$ & Eastman et al. 2008; McAuley et al. 2012; Volk et al. 2014 & 3 \\
\hline 21 & $\begin{array}{l}\text { Requirement of } \\
\text { computable digital } \\
\text { design data (T3) }\end{array}$ & Bernstein, Pittman 2004; Eastman et al. 2008 & 2 \\
\hline 22 & $\begin{array}{l}\text { Lack of cooperation } \\
\text { from other industry } \\
\text { partners (M5) }\end{array}$ & Schlueter, Thesseling 2009 & 1 \\
\hline
\end{tabular}

\subsection{Classification of factors}

For the convenience of analysis, all of the factors in the above list are classified into five categories: Technology, Cost, Management, Personnel, and Legal. These categories include 22 sub-factors, which can be seen in Figure 1.

\section{(1) Technological factors}

The BIM-based software packages are also called BIM tools. The technological factors refer to BIM tool-related factors limiting the application of BIM, such as imperfect or immature BIM software, a lack of standards and protocols, etc. The restricted capabilities of BIM-based software are the main factor limiting its application in the AEC industry. For instance, lack of scalability, interoperability, and support for remote collaboration, and its unsuitability for the production modeling of cast-in-place (CIP) reinforced-concrete structures are the biggest constraints on the mainstream application of BIM (Post 2008; Barak et al. 2009). Interoperability is defined in the IEEE (1990) glossary as "the ability of two or more systems or components to exchange information and to use the information that has been exchanged". Horizontal fragmentation between participants at a given project phase (e.g., design, construction, or operation), can be caused by the diversity of computer software programs and can contribute to the problem of interoperability (Howard et al. 1989). The NIST (National Institute of Standards and Technology) estimates that the total cost of inadequate interoperability is $\$ 15.8$ billion a year (Nisbet, Dinesen 2010). Although software users want to improve the interoperability (Young et al. 2008), and several inter- 


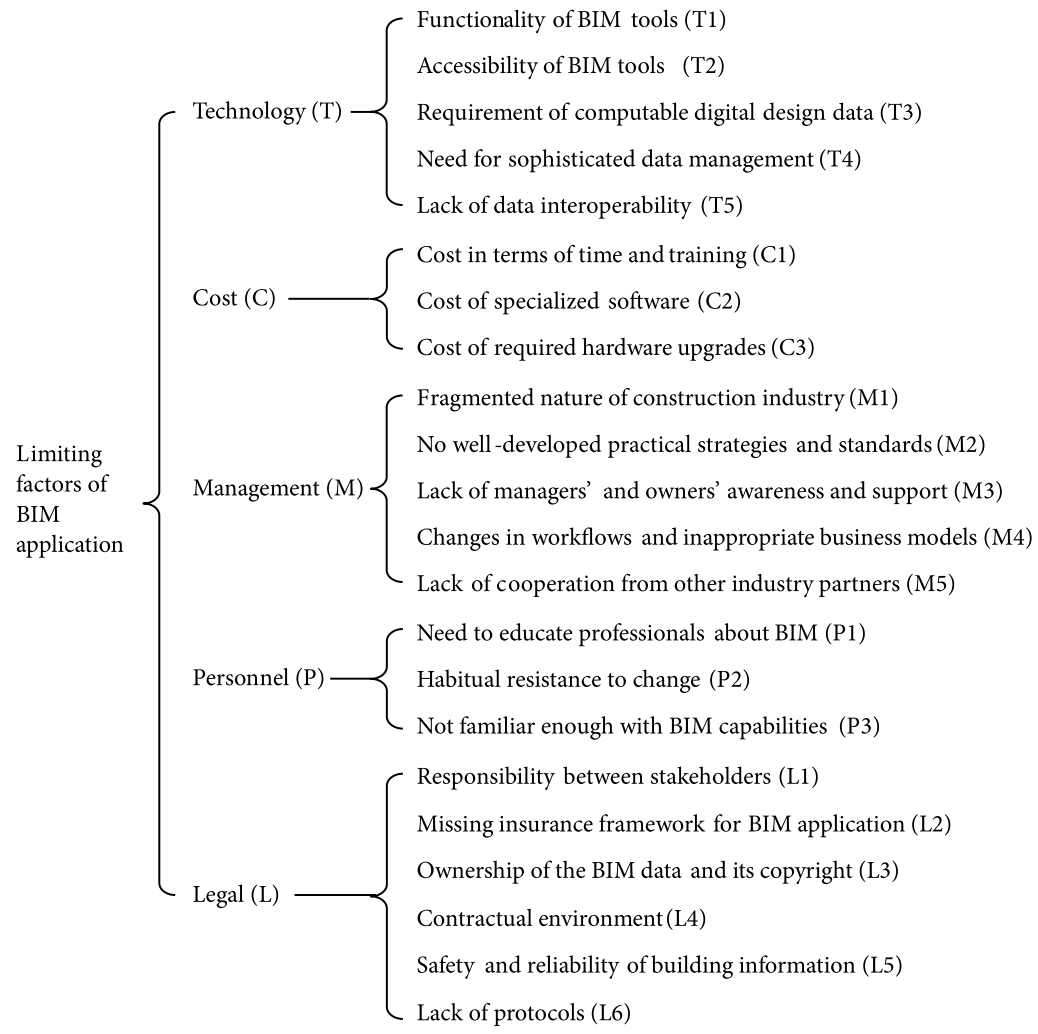

Fig. 1. Categories of factors limiting BIM application

national standards have been developed to address the problems of interoperability, such as STEP and IFCs, there are still a few of shortcomings (Azhar et al. 2011; Rezgui et al. 2011; McAuley et al. 2012). For instance, BIM programs are limited in their static representation of a building and its environment (Rezgui et al. 2011). Besides, the study of synchronization data between BIM and on-site real-time building process is a hotspot over years, many methods and technologies, such as laser scanning, radio frequency identification (RFID), augmented reality (AR), geographic information system (GIS), etc., have been applied to acquire and management these sophisticated data for 'bridging BIM and building (BBB)'. (Chen et al. 2015).

\section{(2) Cost factors}

These major costs referred to in the literature include buying the BIM-based software and hardware, the software service charges, and training costs, etc. Cost factors refer to the money-related limiting factors in the process of BIM application. Hardin (2009), using an example of one user with a mighty set of tools, estimates the cost of using BIM as $\$ 112,100$, including the annual salary of the staff. According to a $2008 \mathrm{McGraw}-\mathrm{Hill}$ survey, costs and training issues have been the greatest barriers to the application of BIM (Young et al. 2008). 


\section{(3) Management factors}

Management factors refer to the process and organization-related limiting factors, and include participants' attitudes toward BIM applications, the lack of existing successful cases and management standards for reference, the fragmented nature of the construction industry, the inappropriate business models, and the lack of cooperation from other industry partners. BIM breaks down the traditional boundaries between firms and enables the sharing of project data in a more collaborative environment (Young et al. 2008). This means that participants must relocate their roles in the project team and change the workflow of their companies in accordance with the requirements of the BIM application. The changes in everything from file management, to client billing, to deliverables, to coordination meetings are multifarious and complicated, and organizations need time to adapt to these changes (Post 2008). Fragmentation is always an important negative factor affecting the productivity and efficiency of construction projects. Many scholars have studied the effects of fragmentation in the AEC industry and have tried to present some solutions to overcome these effects, such as computer integration (Howard et al. 1989; Hwang, Liu 2010). However, Gilligan and Kunz (2007) point out that most participants hesitate to use BIM tools precisely because of the fragmented nature of the construction process, which makes each project unique and not reproducible.

\section{(4) Personnel factors}

Personnel factors refer to the professional-related limiting factors. The lack of experienced personnel who are familiar with BIM and have experience using it is another prominent limiting factor. The training and education of large numbers of professionals is necessary for the wider and better application of BIM. Even in design companies, most designers hesitate to use BIM because of the low efficiency, habitual resistance to change, and heavy work demands encountered during the initial period of setting up BIM tools (Zhang 2010).

\section{(5) Legal factors}

Legal factors refer to the limiting factors caused by the immaturity of contractual/regulatory environment. Legal and insurance ramifications usually caused by imperfect software can result in lawsuits (Barak et al. 2009). Building information models are usually created by different professionals with various software programs and used by different participants. If significant losses occur because of the incorrect use of building information models, claims will become very complicated due to the blurred responsibility. In addition, the regulation of access and the security of building information in building information models (Méndez 2006), ownership and protection of data (McAdam 2010), insurance (Post 2008), protocols (McAuley et al. 2012), etc. must also be resolved.

\subsection{Analysis of factors}

Table 3 shows the frequency with which each of the identified sub-factors appears in the literature review. 
Table 3. Statistics of factors limiting the application of BIM

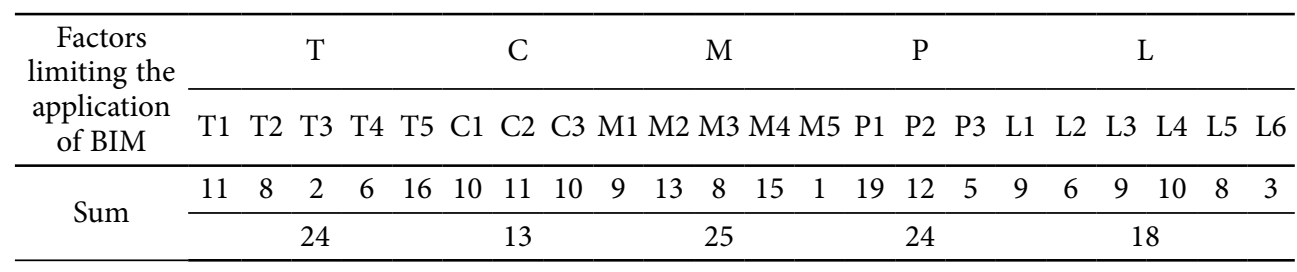

The statistics shown in Table 3 have four implications.

(1) The most frequently cited limiting factors, from most frequent to least frequent, are management factors $(25 / 39=64 \%)$, technology factors $(24 / 39=62 \%)$, personnel factors $(24 / 39=62 \%)$, legal factors $(18 / 39=46 \%)$, and cost factors $(13 / 39=33 \%)$.

(2) Management factors, technology factors and personnel factors have received the most attention, probably because they are the key barriers limiting the application of BIM. Among personnel factors, the sub-factor "Need to educate BIM professionals" received the most attention. It is the most commonly mentioned sub-factor, discussed in 19 studies. It is clear that the lack of BIM professionals is an issue of wide concern, and training large numbers of professionals is an urgent prerequisite for the expansion of BIM. Among technology factors, "lack of data interoperability" is the most commonly mentioned sub-factor and discussed in 16 studies. Among management factors, the sub-factor "changes in workflow and inappropriate business models" has received the most attention and is discussed in 15 studies.

(3) Legal factors have received the fourth most attention. Among legal factors, the sub-factors "contractual environment", "responsibility between stakeholders" and "ownership of the BIM data and its copyright" have received the most attention and are discussed in 10, 9, 9 studies separately.

(4) Although cost is an important factor in the implementation of BIM, few scholars have studied it deeply for the problems associated with cost are very specific and can be easily resolved. Among cost factors, the sub-factor "cost of specialized software" has received the most attention and is discussed in 11 studies.

(5) Among 39 studies, 2 studies were published in 2004, 1 study in 2006, 2 studies in 2007, 6 studies in 2008, 2 studies in 2009, 2 studies in 2010, 5 studies in 2011, 5 studies in 2012, 7 studies in 2013, 5 studies in 2014, and 2 studies in 2015. Studies of the barriers hindering BIM application have become more common in the last years. This means that the ways in which these barriers have blocked the practical application of BIM are now more obvious, as is the urgent need for effective solutions. It also illustrates that more scholars and professionals are being drawn to the study of BIM.

\section{Conclusions and suggestions}

BIM technology has developed very quickly over the last decade. It has been widely used in many huge construction projects, which have proven that great benefits can be achieved by applying BIM. However, there are many barriers limiting the further development and 
application of BIM. Our critical analysis of the literature has led to the development of a general understanding of the factors limiting BIM application. There are five categories of limitations: (1) Technology, (2) Cost, (3) Management, (4) Personnel, and (5) Legal. The most commonly cited categories are Management, Technology and Personnel. Specifically, industry insiders believe that the lack of professionals, lack of data interoperability and changes in workflow are the key barriers to the expansion of BIM.

To facilitate further development and wider application of BIM, we make the following four suggestions according to the five limiting factors identified before.

(1) Concerning the technique limiting factors, researchers and the providers of BIM tools should speed up the development of mature data exchange standards, and focus on creating seamless interoperability among participants with different BIM-tools. IFC is regarded as the best option for achieving interoperability, but some other standards and methods, such as IDM (Information Delivery Manuals), MVD (Model View Definitions) and IFD (International Framework for Dictionaries), also play a significant role to make BIM interoperability a reality (Santos 2009; Volk et al. 2014). Providers of BIM tools should make their products more compatible, user-friendly, and interoperable.

(2) Concerning the cost limiting factors, we think cost should not be key hindrances to BIM implementation, as cost for staff training, software and hardware can be compensated by the great long-term benefits of BIM (Azhar et al. 2011; Jernigan 2007). Furthermore, BIM users (owners, designers, construction companies, consultants, etc.) should adopt BIM as soon as possible, because BIM is the future of the construction industry and in all probability companies that do not adopt it will be eliminated.

(3) Concerning the management limiting factors, first of all, for workflow must be changed to adapt to the new advanced technologies, the problems caused by changes in workflow should be treated with actively. Secondly, researchers should study deeply how BIM can be used in cost management, schedule management, safety management on construction projects, etc., and develop guidelines and standards or strategies for BIM. Thirdly, as far as possible, construction management should adopt IPD (Integrated Project Delivery). As it reduces the effect of fragmentation, the IPD method is a much better construction project delivery method than the traditional design-bid-build delivery method, and there are great benefits to couple BIM to IPD (Ilozor, Kelly 2012). Finally, as the ultimate aim of a construction project is to meet the owner's requirements, owner motivation is the most important factor in BIM application (Nisbet, Dinesen 2010).

(4) Concerning the personnel limiting factors, stakeholders in the construction industry and universities should provide more BIM courses so that students can be familiar with BIM before they start to work. More training is necessary to expand the application of BIM in the construction industry, as research shows that users achieve more positive results from BIM, as they develop higher levels of expertise (Young et al. 2008).

(5) Concerning the legal limiting factors, at the macroscopic level of industry management, joint efforts by governments, industry associations, and corporations are needed to promulgate better laws, regulations, and contract systems for BIM application. In particular, governments should promote BIM in entire industries, as does the American government organization (General Services Administration, GSA) (Eastman et al. 2008). 
Different countries, different time, or even different practical construction projects have different limiting factors, and it is the limitation of the study that didn't distinguish these differences. Concerning the methodological approach, the second search condition does not adopt the negative form of positive outcomes of BIM uses, so some literature may be missed. Furthermore, correlations between limiting factors are too complex so that they have not been studied in this paper. The following research direction is: using the research results of this paper and adopting the questionnaire method, the limiting factors in different applying background and the correlations between limiting factors will be gotten, and this will bring great benefits to practical project.

\section{Acknowledgements}

The authors thank the reviewers and the editor for their helpful comments to improve the quality of this paper. The research was supported by the National Natural Science Foundation of China under the grants No. 71071043, No. 51378160 and No. 71201038, and the Scientific Research Foundation for the Returned Overseas Chinese Scholars of Harbin Science and Technology Bureau of China under the grants No. JJ20120070.

\section{Reference}

Aram, S.; Eastman, C.; Sacks, R. 2013. Requirements for BIM platforms in the concrete reinforcement supply chain, Automation in Construction 35: 1-17. http://dx.doi.org/10.1016/j.autcon.2013.01.013

Arayici, Y.; Khosrowshahi, Y.; Ponting, A. M.; Mihindu, S. 2009. Towards implementation of building information modelling in the construction industry, in Proc. of the 5th International Conference on Construction in the 21st Century (CITC-V-2009), 20-22 May 2009, Istanbul, Turkey.

Arayici, Y.; Coates, P.; Koskela, L.; Kagioglou, M.; Usher, C.; O’Reilly, K. 2011. Technology adoption in the BIM implementation for lean architectural practice, Automation in Construction 20(2): 189-195. http://dx.doi.org/10.1016/j.autcon.2010.09.016

Autodesk, Inc. 2002. Autodesk building industry solutions: building information modeling (white paper) [online], [cited 18 June 2009]. Available from Internet: http://www.laiserin.com

Autodesk, Inc. 2008. The five fallacies of BIM [online], [cited 11 May 2010]. Available from Internet: http://www.cadalyst.com/aec/the-five-fallacies-bim-part-1-1-2-3-revit-tutorial-3688

Autodesk, Inc. 2012. Building information modeling [online], [cited 8 June 2012]. Available from Internet: http://usa.autodesk.com

Azhar, S.; Abid, N.; Mok, J.; Leung, B. 2008. Building information modeling (BIM): a new paradigm for visual interactive modeling and simulation for construction projects, in Proc. of the 1th International Conference on Construction in Developing Countries (ICCIDC-I), 4-5 August 2008, Karachi, Pakistan, 435-446.

Azhar, S.; Hein, M.; Sketo, B. 2011. Building information modeling (BIM): trends, benefits, risks, and challenges for the AEC industry, Leadership and Management in Engineering 11(3): 241-252. http://dx.doi.org/10.1061/(ASCE)LM.1943-5630.0000127

Barak, R.; Jeong, Y. S.; Sacks, R.; Eastman, C. M. 2009. Unique requirements of building information modeling for cast-in-place reinforced concrete, Journal of Computing in Civil Engineering 23(2): 64-74. 
Bernstein, P. G.; Pittman, J. H. 2004. Revit building solutions: barrier to the adoption of building information model in the building industry (white paper). Autodesk, Inc.

Cao, D.; Wang, G.; Li, H.; Skitmore, M.; Huang, T.; Zhang, W. 2015. Practices and effectiveness of building information modelling inconstruction projects in China, Automation in Construction 49: 113-122. http://dx.doi.org/10.1016/j.autcon.2014.10.014

Chen, K.; Lu, W.; Peng, Y.; Rowlinson, S.; Huang, Q. 2015. Bridging BIM and building: from a literature review to an integrated conceptual framework, Internal Journal of Project Management 33(6): 1404-1416. http://dx.doi.org/10.1016/j.ijproman.2015.03.006

Ding, L.; Zhou, Y.; Akinci, B. 2014. Building Information Modeling (BIM) application framework: the process of expanding from 3D to computable nD, Automation in Construction 46: 82-93. http://dx.doi.org/10.1016/j.autcon.2014.04.009

Dong, B.; O’Neill, Z.; Li, Z. 2014. A BIM-enabled information infrastructure for building energy Fault Detection and Diagnostics, Automation in Construction 44: 197-211. http://dx.doi.org/10.1016/j.autcon.2014.04.007

Eadie, R.; Browne, M.; Odeyinka, H.; McKeown, C.; McNiff, S. 2013. BIM implementation throughout the UK construction project lifecycle: an analysis, Automation in Construction 36: 145-151. http://dx.doi.org/10.1016/j.autcon.2013.09.001

Eastman, C.; Teicholz, P.; Sacks, R.; Liston, K. 2008. BIM handbook: a guide to building information modeling for owners, managers, designers, engineers, and contractors. John Wiley \& Sons, Inc., 337338. http://dx.doi.org/10.1002/9780470261309

Fischer, M.; Kunz, J. 2004, The scope and role of information technology in construction [online], [cited 12 November 2010]. Available from Internet: www-leland.stanford.edu

Gerber, B. B.; Gerber, D .J.; Ku, K. 2011. The pace of technological innovation in architecture, engineering, and construction education: integrating recent trends into the curricula, Journal of Information Technology in Construction 16: 411-432.

German, P. 2012. Evaluation of training needs for Building Information Modeling (BIM). ProQuest, UMI Dissertation Publishing.

Giel, B. K.; Issa, R. A. 2011. BIM return on investment: a case study, Journal of Building Information Modeling Spring: 24-27.

Giel, B. K.; Issa, R. A. 2013. Return on investment analysis of using building information modeling in construction, Journal of Computing in Civil Engineering 27(5): 511-521. http://dx.doi.org/10.1061/(ASCE)CP.1943-5487.0000164

Gilligan, B.; Kunz, J. 2007. VDC Use in 2007: significant value, dramatic growth, and apparent business opportunity (CIFE technical reports) [online], [cited 11 December 2010]. Available from Internet: http://cife.stanford.edu

Gledson, B.; Henry, D.; Bleanch, P. 2012. Does size matter? Experiences and perspectives of BIM implementation from large and SME construction contractors, in Proc. of 1st UK Academic Conference on Building Information Management (BIM), 5-7 September 2012, Northumbria University, Newcastle upon Tyne, UK, 5-7.

General Services Administration (GSA). 2007. GSA building information modeling guide series 01 overview [online], [cited 14 May 2010]. Available from Internet: http://www.gsa.gov

Gu, N.; Singh, V.; Taylor, C.; London, K.; Brankovic, L. 2007. Building Information Modelling - an issue of adoption and change management, in Proc. of Innovative Community Action Networks Conference (ICAN-2007), 28 August 2007, Sydney, Australia.

Gupta, A.; Cemesova, A.; Hopfe, C. J.; Rezgui, Y.; Sweet, T. 2014. A conceptual framework to support solar PV simulation using an open-BIM data exchange standard, Automation in Construction 37: 166-181. http://dx.doi.org/10.1016/j.autcon.2013.10.005 
Hardin, B. 2009. BIM and construction management: proven tools, methods, and workflows. Indianapolis, Indiana: Wiley Publishing, Inc.

Harness, S. H. 2008. 2008 documents AIA advance the use of BIM and integrated project delivery [online], [cited 5 December 2008]. Available from Internet: http://www.aia.org

Hartmann, T.; Fischer, M. 2008. Applications of BIM and teaching strategy for widespread adoption of BIM, Stanford University [online], [cited 9 August 2009]. Available from Internet: http://cife. stanford.edu

Howard, H. C.; Levitt, R. E.; Paulson, B. C.; Pohl, J. G.; Tatum, C. B. 1989. Computer integration: reducing fragmentation in AEC industry, Journal of Computing in Civil Engineering 3(1): 18-32. http://dx.doi.org/10.1061/(ASCE)0887-3801(1989)3:1(18)

Howell, I.; Batcheler, B. 2004. Building information modeling two years later - huge potential, some success and several limitations. Newforma white paper. $8 \mathrm{p}$.

Hwang, S.; Liu, L. Y. 2010. BIM for integration of automated real-time project control systems, Construction Research Congress 509-517. http://dx.doi.org/10.1061/41109(373)51

IEEE. 1990. IEEE standard computer dictionary: a compilation of IEEE standard computer glossaries. New York, NY: IEEE. 114 p.

Ilozor, B. D.; Kelly, D. J. 2012. Building information modeling and integrated project delivery in the commercial construction industry: a conceptual study, Journal of Engineering, Project, and Production Management 2(1): 23-36.

Jensen, P. A.; Jóhannesson, E. 2012. Building information modelling in Denmark and Iceland, Engineering, Construction and Architectural Management 20(1): 99-110. http://dx.doi.org/10.1108/09699981311288709

Jernigan, F. E. 2007. Big BIM little BIM - the practical approach to building information modeling. Salisbury: 4Site Press.

Kim, H.; Anderson, K. 2012. Energy modeling system using building information modeling (BIM) open standards, Journal of Computing in Civil Engineering 27(3): 203-211. http://dx.doi.org/10.1061/(ASCE)CP.1943-5487.0000215

Laiserin, J. 2002. Comparing Pommes and Naranjas [online], [cited 13 November 2010]. Available from Internet: http://www.laiserin.com

McAdam, B. 2010. Building information modeling: the UK legal context, International Journal of Law in the Built Environment 2(3): 246-259. http://dx.doi.org/10.1108/17561451011087337

McAuley, B.; Hore, A.V.; West, R. 2012. Implementing of building information modelling in public works projects, in Proc. of the 9th European Conference on Product and Process Modelling, 25-27 July 2012, Reykjavik, Iceland.

Miettinen, R.; Paavola, S. 2014. Beyond the BIM utopia: approaches to the development and implementation of building information modeling, Automation in Construction 43: 84-91. http://dx.doi.org/10.1016/j.autcon.2014.03.009

Méndez, R. O. 2006. The building information model in facilities management: Master's thesis. Worcester Polytechnic Institute.

Migilinskas, D.; Popov, V.; Juocevicius, V.; Ustinovichius, L. 2013. The benefits, obstacles and problems of practical BIM implementation, Procedia Engineering 57: 767-774. http://dx.doi.org/10.1016/j.proeng.2013.04.097

National Institute of Builkding Sciences (NIBS). 2007. National BIM Standard Version 1 - Part 1: Overview, Principles, and Methodologies [online], [cited 18 December 2009]. Available from Internet: http://www.wbdg.org

Nejat, A.; Darwish, M.; Ghebrab, T. 2012. BIM teaching strategy for construction engineering students, in Proc. of American Society for Engineering Education 2012 Annual Conference, 10-13 June 2012, San Antonio, Texas. 
Nisbet, N.; Dinesen, B. 2010. Constructing the business case: Building Information Modeling. British Standards Institution and BuildingSMART, UK.

Pihlak, M.; Deamer, P.; Holland, R.; Poerschke, U.; Messner, J.; Parfitt, K. 2011. Building Information Modeling (BIM) and the impact on design quality, Journal of Architectural Engineering Technology 1(1): 1-6. http://dx.doi.org/10.4172/2168-9717.1000101

Porwal, A.; Hewage, N. K. 2013. Building Information Modeling (BIM) partnering framework for public construction projects, Automation in Construction 31: 204-214.

http://dx.doi.org/10.1016/j.autcon.2012.12.004

Post, N. M. 2008. Building Information Modeling snags don't dampen spirits, ENR: Engineering NewsRecord 261(17): 30-32.

Rezgui, Y.; Boddy, S.; Wetherill, M.; Cooper, G. 2011. Past, present and future of information and knowledge sharing in the construction industry: towards semantic service-based e-construction?, Computer Aided Design 43(5): 502-515. http://dx.doi.org/10.1016/j.cad.2009.06.005

Rezgui, Y.; Beach, T.; Rana, O. 2013. A governance approach for BIM management across lifecycle and supply chains using mixed-modes of information delivery, Journal of Civil Engineering and Management 19(2): 239-258. http://dx.doi.org/10.3846/13923730.2012.760480

Sacks, R.; Barak, R. 2010. Teaching Building Information Modeling as an integral part of freshman year civil engineering education, Journal of Professional Issues in Engineering Education and Practices 136(1): 30-38. http://dx.doi.org/10.1061/(ASCE)EI.1943-5541.0000003

Santos, E. T. 2009. Building Information Modeling and interoperability [online], [cited 25 June 2014]. Available from Internet: http://cumincades.scix.net

Schlueter, A.; Thesseling, F. 2009. Building information model based energy/exergy performance assessment in early design stages, Automation in Construction 18(2): 153-163.

http://dx.doi.org/10.1016/j.autcon.2008.07.003

Singh, V.; Gu, N.; Wang, X. 2011. A theoretical framework of a BIM-based multi-disciplinary collaboration platform, Automation in Construction 20(2): 134-144.

http://dx.doi.org/10.1016/j.autcon.2010.09.011

Succar, B. 2009. Building information modelling framework: a research and delivery foundation for industry stakeholders, Automation in Construction 18: 357-375.

http://dx.doi.org/10.1016/j.autcon.2008.10.003

Tekla Corporation. 2013, Basic concepts [online], [cited 16 January 2013]. Available from Internet: http://www.tekla.com

Volk, R.; Stengel, J.; Schumann, F. 2014. Building Information Modeling (BIM) for existing buildings literature review and future needs, Automation in Construction 38: 109-127. http://dx.doi.org/10.1016/j.autcon.2013.10.023

Yan, H.; Damian, P. 2008. Benefits and barriers of Building Information Modelling, in Proc. of the 12th International Conference on Computing in Civil and Building Engineering (ICCCBE-2008), 16-18 October 2008, Beijing, China, 1-5.

Young, N. W.; Jones, S. A.; Bernstein, H. M. 2008. Transforming design and construction to achieve greater industry productivity: SmartMarket report on building information modeling (BIM). McGraw-Hill.

Zhang, J. 2010. Study on barriers of Implementing BIM in engineering design industry in China, Journal of Engineering Management 24(4): 387-392. (in Chinese).

Zhang, D.; Gao, Z. 2013. Project time and cost control using building information modeling, in Proc. of the International Conference on Construction and Real Estate Management (ICCREM-2013), 10-11 October 2013, Karlsruhe, German, 545-554. 
Chengshuang SUN. Doctor, Associate Professor and Head of Department of Real Estate and Construction, School of Management, Harbin Institute of Technology, Harbin, China. Member of Professional Committee of Management Modernization, China Construction Industry Association.

Author and co-author of more than 30 scientific articles. Research interests: Building Information Modeling, construction project risk management, sustainable development.

Shaohua JIANG. Doctor, Associate Professor of Department of Construction Management, Faculty of Infrastructure Engineering, Dalian University of Technology, Dalian, China.

Author and co-author of more than 40 cientific articles and 3 books. Research interests: Construction project information and knowledge management, Building Information Modeling, Intelligent construction management based on Internet and Internet of Things, Decision support tools for project management and construction, Construction project risk management, Infrastructure sustainability.

Miroslaw J. SKIBNIEWSKI. Doctor, Professor of Civil \& Environmental Engineering, A.J. Clark School of Engineering, University of Maryland, College Park, USA. Foreign Member of the Russian Academy of Engineering and the Academy of Engineering in Poland, Member of American Society of Civil Engineers (ASCE).

Author and co-author of more than 200 scientific articles and 5 books. Research interests: construction engineering and management, automation and robotics, information technology.

Qingpeng MAN. Doctor, Associate Professor and Vice Head of Department of Real Estate and Construction, School of Management, Harbin Institute of Technology, Harbin, China. Member of Construction Economy Committee, Architectural Society of China.

Author and co-author of more than 25 scientific articles and 1 book. Research interests: infrastructure management, construction risk management, and information management in construction.

Liyin SHEN. Doctor, Distinguished Professor and Associate Dean, School of Construction Management and Real Estate, Director of International Research Centre for Sustainable Built Environment, Chongqing University, China. Editor-in-Chief, International Journal of Construction Management.

Author and co-author of more than 150 International Journal articles and 9 books. Research interests: sustainable construction and urban development, construction and real estate enterprise competitiveness, construction and real estate risk management. 